\title{
Improving the Wellbeing of Ikot Ene During the COVID-19 Lockdown: The Role of Justice, Development and Peace/Caritas Advocates (JDPCA)
}

\author{
Emmanuel M. Bekomsom ${ }^{\mathrm{a}}$, James A. Ogar ${ }^{\mathrm{a}}$, Abayomi I. Akintola ${ }^{\mathrm{a}}$, Emmanuella Dike ${ }^{\mathrm{a}}$, Tangban \\ Egbe $^{\mathrm{b}} \&$ Francis E. Ibioro ${ }^{\mathrm{a}} \&$ Adeolu Ayodele ${ }^{\mathrm{c}}$ \\ ${ }^{a}$ University of Calabar, P.M.B. 1115, Cross River state, Nigeria \\ ${ }^{b}$ Department of Social Work, University of Calabar, Nigeria \\ ${ }^{c}$ Birmingham City University, United Kingdom
}

\begin{abstract}
The study's objective is to examine the relationship between Justice, Development and Peace/Caritas Advocates (JDPCA) activities and the Wellbeing of Ikot Ene people during COVID-19 Lockdown. Specifically, the study examines the relationship between JDPCA's provision of palliatives, healthcare programmes, and the Wellbeing of Ikot Ene people during COVID-19 Lockdown. Two research questions and null hypotheses were raised for the study. Literature was reviewed according to the variables of the study. The survey research design was adopted in collecting data from 176 samples from a population of 725 beneficiaries of the JDPCA programme from Ikot Ene in Akpabuyo Local government Area of Cross River state. The instrument of data collection was the question. Data collected from the field was analyzed using descriptive and inferential statistics. Result revealed a correlation between JDPCA's provision of palliatives; healthcare programmes had a significant impact on the Wellbeing of the people of Ikot Ene. During COVID-19 Lockdown. Based on the study's findings, the study recommends a need for the Justice, Development and Peace/Caritas Advocates (JDPCA) to improve their coverage area and the number of beneficiaries for their future programmes.
\end{abstract}

Keywords: JDPCA, provision of palliatives, healthcare programmes, Wellbeing, Ikot Ene.

\section{Introduction}

The COVID-19 pandemic, which started in the late period of the 2019 in the Wuhan province of China, has swept across the globe, causing an unprecedented health catastrophe and challenge unseen since the second world war (Harper, Kaita, becker, Haifa, Nieuwhof-Leppink, Fossum, Herbert, Bagli and ESPU Research Committee, 2020; Baloch, Baloch, Zheng \& Pei, 2020; Omang, Angioha, Ojong-Ejoh \& Abang, 2020; Ojong-Ejoh, Angioha, Agba, Aniah, Salimon, \& Akintola, 2021; Omang \& Angioha, 2021), putting severe strain on global health services as well as its personnel. The virus, with pneumonia-like symptoms, have caused hundreds of deaths, shut down the economy of affected nations (Paudel \&Subedi, 2020). As of February 2020, there were 106,715,549 reported cases of the virus, with a reported 2,328,060 deaths globally (United Bations, 2021; World Bank, 2021). According to the World Bank (2021), the pandemic will push an estimated 150 million people globally into extreme poverty. The report states that most of the new poor will be found in nations with a high poverty rate. Eighty-two per cent of the new poor, approximately 8 out of 10 new poor, will be from developing countries (Andren, Edeh, Aboh, Paulo \& Thurlow,2020; World Bank,2020). With the growing extreme poor, food will become a problem. The world food programme (2020) the pandemic will make an additional 83 to 132 million people undernourished even in nations not facing famine, the disruption of food supply and the loss of income from loss of livelihood as a result of the pandemic implies that millions are now finding it difficult to get food to eat. (World Food Programme, 2020).

\footnotetext{
* Corresponding author

E-mail address: beksmune@gmail.com (Emmanuel M. Bekomson)
} 
Since the index case was first reported in February 2020, Nigeria have been adversely affected by the pandemic. As of 11th February 2020, there were 142,578 reported cases and 1702 confirmed deaths (Africa news, 2020; NCDC,2021). The diagnosis of the index cases in Nigeria set up a chain of policy actions and measures, including health and educational campaigns, restriction, lockdown, monetary efforts (Andam, Edeh, Oboh, Pauw \& Thaulow, 2020). Apart from the pandemic's tremendous health hazard and human consequence, the economic uncertainties and disruption have brought untold hardship on ordinary Nigerian due to the stringent measures and policies to fight the pandemic (Stanley, Nkporbu, \& Stanley, 2020). The economic shock resulting from the pandemic and government policies to curb the pandemic has affected Nigerian households, depleting the income and food resource, especially those in rural communities.

Donor agencies, private organizations and the government, whose aim has been to reduce global poverty, have been asked to play a more significant role in addressing the rising effect of the COVID-19. They have been asked to assess the socioeconomic challenges of the pandemic. According to the World Bank (2020), estimates that donor agencies and government-led findings have report assisted 1.8 billion people during the pandemic. In Nigeria, for several years, Non-Governmental Agencies have been actively involved in compacting various challenges related to development such as education, women, poverty, child protection, social justice, and human rights. Various NGOs have been taking various initiatives to help combat the pandemic's socioeconomic effect. One of such NGOs in the catholic church justice, development and peace Caritas Advocate. The organization is a faith-based non-profit organization of the catholic Archdiocese committed to promoting holistic human development for humanity through capacity building, peacebuilding, community mobilization, women mobilization, human right and environmental care. With COVID-19 ravaging the world, the organization carried out various programmes to alleviate the people's plight, especially in rural areas. This study aims to assess the impact of justice, development and peace advocate activities and Wellbeing of people in Ikot Ene, Akpabuyo Local Government Area of Cross River during the COVID-19 pandemic.

\section{Methods}

\subsection{Research Design}

The survey research design was adopted for the study. The design allows the researcher to collect data on a particular sociological issue from a population sample or subunit (Iji, Ojong, \& Angioha, 2018; Ndem, Angioha, \& Dike, 2020; Angioha, Nwagboso, Ironbar \& Ishie, 2018). Used in studies where the researcher tries to analyse the relative incidence and the interrelatedness of variables, it is used only in studies where the investigation unit is human.

\subsection{Study Area}

The study was carried out in Ikot Ene Community of Akpabuyo Local Government Area of Cross River state. Akpabuyo is one of the local Government Area in Southern Cross River State. Covering an area of 1,241 $\mathrm{Km}^{2}$, with a population of 271,395 according to the 2006 National Population Census, the Local government area lies between latitude $4^{0} 45^{\prime \prime} \mathrm{N}$ and $5010^{\prime \prime} \mathrm{S}$ and longitude $8^{0} 25 \mathrm{~W}$ and $8^{0} 40^{\prime \prime} \mathrm{E}$ of the Greenwich Meridian. The Local Government Area is situated in Southern Nigeria's vegetative Belt and the Atlantic Coastline's shores with the Republic of Cameroun to the West and Bakassi to the East. Known as the Food basket of Cross River State, the area's primary economic activities are agriculture, with Cassava, Cocoyam, Kolanut, maize the primary agriculture product (Ukwayi, Angioha \& Ayi, 2018). The Local Government Area comprises 28 autonomous villages in which the primary study area, Ikot Ene, is a part. The Local Government Area is rich in minerals, including Limestone, gold, salt, etc., available in large quantities for commercial purposes.

\subsection{Population and Sampling}

The study population are the people of Ikot Ene in Akpabuyo Local Government Area who benefited from JDPCA programs during the COVID-19 pandemic. According to the office of JDPCA in Calabar, there were 725 beneficiaries of their program during the COVID-19 pandemic. The study's sample size is 196, arrived at using the Survey Monkey Sampling Determinant Technique at 95 per cent confidence level and a margin of error of 5 per cent. The purposive and snowball sampling technique was used in selecting the sample from the study area. The purposive sampling technique was used in selecting Ikot Ene from Akwa Ibom Local Government Area. Ikot Ene Because this was the area where the program by JDCPSA was Carried out. The researcher then used the snowball sampling technique was 
used in selecting 196 from the study area. With the program coordinator's help, the researcher was able to locate five (5) of the beneficiaries. The five beneficiaries were then able to direct the researcher to other beneficiaries, who also directed the researcher to other beneficiaries until the needed samples was located.

\subsection{Instrumentation}

A structured questionnaire was used to generate the data for the study. The questionnaire was designed in a Likert scale format of 4 points, designed in a way that the participants would understand. The questionnaire was divided into two sections. Section A was designed to elicit information on the demographic data of the respondents. Section B was designed to help elicit information on the study variables and was further divided into two subsections according to the study's number of independent variables.

\subsection{Ethical Consideration}

A letter of approval was obtained from the office of Justice, Development and Peace/Caritas Advocates (JDPCA) for a study of this nature to be carried out. The researcher also obtained verbal permission from the study sample to include the written ethical letter attached to each instrument. The anonymity of each respondent was assured.

\subsection{Method of data analysis}

Data collected from the field was coded and entered into the statistical package for Social Sciences (SPSS) version 20. For descriptive analysis, frequency distribution, simple percentage, graphical illustration and table was used to analyze the data. To check the Correlation between the variables under study, Pearson Product Moment Correlation was used at 0.05 confidence level. Out of the 196-instrument distributed, only 157 instruments were returned without missing items or mutilation.

\subsection{Description of Variables}

The study's main objective is to examine the relationship between Justice, Development and Peace/Caritas Advocates (JDPCA) and the Wellbeing of Ikot Ene people during COVID-19 Lockdown. The study specifically;

(i) Examine the relationship between JDPCA's provision of palliatives and the Wellbeing of the people of Ikot Ene During COVID-19 Lockdown

(ii) Examine the relationship between JDPCA's healthcare programmes and the Wellbeing of the people of Ikot Ene During COVID-19 Lockdown

\subsection{Research Hypotheses}

(i) There is no significant relationship between JDPCA's provision of palliatives and the Wellbeing of the people of Ikot Ene During COVID-19 Lockdown;

(ii) There is no significant relationship between JDPCA's healthcare programmes and the Wellbeing of the people of Ikot Ene during the COVID-19 Lockdown.

\section{Findings and Discussions}

\subsection{Presentation of Results}

\subsubsection{Objective one}

Examine the relationship between JDPCA's provision of palliatives and the Wellbeing of Ikot Ene people during COVID-19 Lockdown. Frequency and percentages were first used to answer this research question and reported in Table 1 before the data were subjected to parametric statistics to test for statistical significance and reported in Table 2 .

Table 1. Responses on JDPCA's provision of palliatives 


\begin{tabular}{llllll}
\hline SN & Provision of palliatives & SA & A & D & SD \\
\hline 1 & The COVID-19 pandemic period was difficult for & 78 & 71 & $8(5.1)$ & 0 \\
& my family and me & $(49.7)$ & $(45.2)$ & & \\
2 & I benefitted from the palliative of JDCPA & 104 & 53 & 0 & 0 \\
& & $(66.2)$ & $(33.8)$ & & \\
3 & The palliative was enough to take care of my family & 24 & 62 & 37 & 34 \\
& $\begin{array}{l}\text { and me during the pandemic } \\
4\end{array}$ & $(15.3)$ & $(39.5)$ & $(23.6)$ & $(21.7)$ \\
& It would have been difficult for my family and me if & 25 & 83 & 31 & 18 \\
not for the palliatives from JDCPA & $(15.9)$ & $(52.9)$ & $(19.7)$ & $(11.5)$ \\
\hline
\end{tabular}

*Percentages are written in parenthesis

For reporting purposes, strongly agree and agree was reported as agreed, while disagree and strongly disagree was said as disagreed. Table 2 indicates responses to sub-scale on team motivation. As presented in Table 2, out of the 157 respondents used in this study, more than half, 149 (94.5\%) of the respondents claimed that the COVID-19 pandemic period was difficult for my family and me; 157 (100\%) holds that they benefitted from the palliative of JDCPA; 86 (54.8\%) claimed that the palliative was enough to take care my family and I during the pandemic; 108 (68.8\%) claimed that It would have been difficult for my family and me if not for the palliatives from JDCPA.

\subsubsection{Hypothesis one}

There is no significant relationship between JDPCA's provision of palliatives and the Wellbeing of the people of Ikot Ene During COVID-19 Lockdown. The independent variable in this hypothesis is JDPCA's provision of palliatives, while the dependent variable is the Wellbeing of the people. Pearson product-moment correlation coefficient was used to test this hypothesis at 0.05 level of significance, and the result is presented in Table 2 .

Table 2. Pearson product-moment correlation of JDPCA's provision of palliatives and Wellbeing

\begin{tabular}{lccccc}
\hline Variable & $\mathrm{N}$ & Mean & SD & r-value & Sig. \\
\hline JDPCA's provision of palliatives & 157 & 15.24 & 2.63 & & \\
Wellbeing & 157 & 11.08 & 2.66 & $0.447^{* *}$ & .000 \\
\hline
\end{tabular}

*significant at 0.05 level; $\mathrm{df}=155$; critical $\mathrm{r}$ value $=0.098$

The result in Table 4 revealed that the calculated $\mathrm{r}$-value of $0.447^{* *}$ is greater than the critical $\mathrm{r}$-value of 0.098 at a 0.05 level of significance with 155 degrees of freedom. By this result, the null hypothesis, which states that there is no significant relationship between JDPCA's provision of palliatives and the Wellbeing of the people of Ikot Ene During COVID-19 Lockdown, is rejected the alternate hypothesis is accepted. The correlation coefficient is a standardized measure of an observed effect; it is a commonly used measure of an impact's size. The values of \pm .1 represent a small effect, \pm .3 is a medium effect, and \pm .5 is a significant effect.

Therefore, the squared Correlation $(0.447)^{2}$, a measure of effect size, indicates the proportion of explained variance on the dependent variable. Thus, $19.9 \%$ of the variance in the Wellbeing of the people is accounted for by JDPCA's provision of palliatives. Therefore, we can conclude that there is a significant statistical relationship between JDPCA's provision of palliatives and the Wellbeing of Ikot Ene's people.

\subsubsection{Objective two}

Examine the relationship between JDPCA's healthcare programmes and the Wellbeing of the people of Ikot Ene During COVID-19 Lockdown. Frequency and percentages were first used to answer this research question and reported in Table 3 before the data were subjected to parametric statistics to test for statistical significance and reported in Table 5.

Table 3. Responses on JDPCA's healthcare programmes 


\begin{tabular}{llllll}
\hline SN & Healthcare programmes & SA & A & D & SD \\
\hline 1 & $\begin{array}{l}\text { JDPCA held healthcare programmes that helped } \\
\text { during the COVID-19 pandemic }\end{array}$ & $\begin{array}{l}104 \\
(66.2)\end{array}$ & $\begin{array}{l}(28.7) \\
25\end{array}$ & & $8(5.1)$ \\
2 & $\begin{array}{l}\text { A lot of people fell sick during the COVID-19 } \\
\text { lockdown }\end{array}$ & $8(5.1)$ & 24 & 45 & 80 \\
& $\begin{array}{l}\text { The health programme taught people on how to } \\
\text { prevent contacting COVID-19 virus }\end{array}$ & $\begin{array}{l}(15.3) \\
(24.2)\end{array}$ & $\begin{array}{l}(28.7) \\
(64.3)\end{array}$ & $8(5.1)$ & $10(6.4)$ \\
& $\begin{array}{l}\text { Health products that will help prevent the spread of } \\
\text { COVID-19 was distributed }\end{array}$ & 70 & 0 & $10(6.4)$ \\
& $(49.0)$ & $(44.6)$ & & \\
\hline
\end{tabular}

*Percentages are written in parenthesis

Source: Field survey, 2021

For reporting purposes, strongly agree and agree was reported as agreed, while disagree and strongly disagree was said as disagreed. Table 3 indicates responses to sub-scale on team training. As presented in Table 3, out of the 157 respondents used in this study, more than half 149 (94.5\%) of the respondents claimed that JDPCA held healthcare programmes that helped during the COVID-19 pandemic; 139 (88.5\%) holds the view that the health programme taught people on how to prevent contacting COVID-19 virus; 147 (93.6\%) claimed that Health products that will help prevent the spread of COVID-19 were distributed.

\subsubsection{Hypothesis two}

There is no significant relationship between JDPCA's healthcare programmes and the Wellbeing of the people of Ikot Ene During COVID-19 Lockdown. The independent variable in this hypothesis is JDPCA's healthcare programmes, while the dependent variable is the Wellbeing of the people. Pearson product-moment correlation coefficient was used to test this hypothesis at 0.05 level of significance, and the result is presented in Table 5 .

Table 4. Pearson product-moment correlation of JDPCA's healthcare programmes and Wellbeing

\begin{tabular}{lccccc}
\hline Variable & $\mathrm{N}$ & Mean & SD & r-value & Sig. \\
\hline JDPCA's healthcare programmes & 157 & 15.02 & 1.99 & & \\
& & & & $0.153^{*}$ & .042 \\
Wellbeing & 157 & 11.08 & 2.66 & & \\
\hline
\end{tabular}

*significant at 0.05 level; $\mathrm{df}=155$; critical $\mathrm{r}$ value $=0.098$

The result in Table 6 revealed that the calculated r-value of $0.153^{*}$ is greater than the critical $r$-value of 0.098 at 0.05 level of significance with 155 degrees of freedom. By this result, the null hypothesis states that there is no significant relationship between JDPCA's healthcare programmes and the Wellbeing of the people of Ikot Ene During COVID19, Lockdown is rejected while the alternate hypothesis is accepted. The correlation coefficient is a standardized measure of an observed effect. It is a commonly used measure of the size of an effect, and that values of \pm .1 represent a small effect, \pm .3 is a medium effect, and \pm .5 is a significant effect.

The squared Correlation $(0.153)^{2}$, which is a measure of effect size, indicates the proportion of explained variance on the dependent variable. Therefore, $2.3 \%$ of the variance in the Wellbeing of the people of Ikot Ene is accounted for by JDPCA's healthcare programmes. The magnitude of the effect is small. Therefore, we can conclude from this result that there is a significant statistical relationship between JDPCA's healthcare programmes and the Wellbeing of the people of Ikot Ene During the COVID-19 Lockdown.

\section{Discussion of Findings}

The result from the first hypothesis revealed a significant statistical relationship between JDPCA's provision of palliatives and the Wellbeing of the people of Ikot Ene. During COVID-19 Lockdown. The result is so because the calculated $\mathrm{r}$-value of $0.447^{* *}$ is greater than the critical r-value of 0.098 at 0.05 level of significance with 155 degrees of freedom. Also, the squared Correlation $(0.447)^{2}$, which is a measure of effect size, indicates the proportion of explained variance on the dependent variable. Therefore, $19.9 \%$ of the variance in the Wellbeing of the people is 
accounted for by JDPCA's provision of palliatives. From the descriptive analysis carried out, all the respondents reported that they benefitted from the programmes of JCDPA. Fifty-four per cent said that the palliative was enough to take care of my family and me during the pandemic. Sixty-eight per cent reported it would have been difficult to survive without the scheme. With this result, it is concluded that the JDPCA's provision of palliatives has had a significant impact on the Wellbeing of Ikot Ene's people. During COVID-19 Lockdown. Studies of similar natures support this finding. Kumar, Kodidela, Kumar, Gerth and Zhi (2020) found that the intervention strategy showed improved Wellbeing for basic science researchers, which was also consistent with their improved productivity during the COVID-19 era. Awofeso and Irabor (2020) found that Palliative measures introduced by the government to minimize the effect of the COVID-19 pandemic are largely ineffective due to poor coordination, human rights violations, and inadequate fiscal policy. Akatugba, Oniore and Akekere (2016) found that the long-run determinants of economic development, measured by per capita income, are primarily from IFAD funded project inputs in Nigeria (IFPN) and life expectancy in Nigeria (LERN).

The result from the second hypothesis revealed that there is a significant statistical relationship between JDPCA's healthcare programmes and the Wellbeing of the people of Ikot Ene During COVID-19 Lockdown. The result is so because the calculated $r$-value of $0.153 *$ is greater than the critical $r$-value of 0.098 at 0.05 level of significance with 155 degrees of freedom. Also, the squared Correlation $(0.153)^{2}$, which is a measure of effect size, indicates the proportion of explained variance on the dependent variable. Therefore, $2.3 \%$ of the variance in the Wellbeing of the people of Ikot Ene is accounted for by JDPCA's healthcare programmes. From the descriptive analysis carried out, 88.5 per cent of the respondents reported that the health programme taught people how to prevent contacting COVID19 virus; 147 (93.6\%) claimed that Health products would help prevent the spread of COVID-19 was distributed. Based on this, we can conclude that the JDPCA health programme has helped reduce the spread of COVID-19 in Ikot Ene.

This finding is supported by that of Mercer (2004), whose results indicate relatively high coverage has been achieved for reproductive and child health services and lower infant and child mortality by NGOs. The United Nations Office's report for the Coordination of Humanitarian Affairs (2020) found that CARE Sudan set up isolation centres in health facilities across the state and trained 150 community volunteers to carry out COVID-19 specific awareness campaigns.

\section{Conclusion and Recommendation}

The study aimed to analyse the impact of the Justice, Development and Peace/Caritas Advocates (JDPCA) on the Wellbeing of the people of Ikot Ene in Akpabuyo Local Government Area of Cross River State. The data analyzed using descriptive and Correlation analysis results revealed that the JDPCA activities significantly impact Ikot Ene's people's lives. Based on this finding, the study recommends that;

(i) There is a need for the Justice, Development and Peace/Caritas Advocates (JDPCA) to improve their area of coverage and the number of beneficiaries for their future programmes.

(ii) There is a need for other donor agencies to carry out other programmes in Ikot Ene and its environment. A visit to Ikot Ene and its environment will Reveal a high poverty rate, lack of infrastructures etc.

\section{References}

AfricanNews (2021). Coronavirus - Nigeria: COVID-19 update (7 February https://www.africanews.com/2021/02/08/coronavirus-nigeria-COVID-19-update-7-february-2021//

Andam, K., Edeh, H., Oboh, V., Pauw, K., \& Thurlow, J. (2020). Impacts of COVID-19 on food systems and poverty in Nigeria. Advances in Food Security and Sustainability, 5, 145-173. https://doi.org/10.1016/bs.af2s.2020.09.002 
Angioha, P. U., Nwagboso, S. N., Ironbar, A. E. \& Ishie, E. U. (2018). Underemployment: A Sociological and Policy Analysis of Workers Well-Being in Hospitality Industry in Calabar, Cross River State, Nigeria. IOSR Journal of Humanities and Social Science (IOSR-JHSS), Volume 23, Issue 6, Ver. 5 (June. 2018) PP 57-66.

Awofeso, O., \& Irabor, P. A. (2020). Assessment of Government Response to Socioeconomic Impact of COVID-19 Pandemic in Nigeria. Journal of Social and Political Sciences, 3(3), 1. https://doi.org/10.31014/aior.1991.03.03.201

Bambra, C., Riordan, R., Ford, J., \& Matthews, F. (2020). The COVID-19 pandemic and health inequalities. Journal of Epidemiology and Community Health, jech-2020. https://doi.org/10.1136/jech-2020-214401

Harper, L., Kalfa, N., Beckers, G.M.A, Kaefer, M., Nieuwhof-Leppink, A. J., Fossum, M. (2020). The impact of COVID-19 on research. J Pediatr Urol 2020;16:715-6. https://doi.org/10.1016/j.jpurol.2020.07.002.

Iji, M. E., Ojong, F. \& Angioha, P. U. (2018). Microfinance Credit Programmes: Implications on Poverty Reduction in Southern Senatorial District of Cross River State, Nigeria. IOSR Journal Of Humanities And Social Science (IOSR-JHSS) Volume 23, Issue 6, Ver. 6 (June. 2018) PP 38-45.

Kumar, S., Kodidela, S., Kumar, A., Gerth, K., \& Zhi, K. (2020). Intervention and Improved Wellbeing of Basic Science Researchers During the COVID 19 Era: A Case Study. Frontiers in Psychology, 11, 1. https://doi.org/10.3389/fpsyg.2020.574712

Mercer, A. (2004). Effectiveness of an NGO primary health care programme in rural Bangladesh: evidence from the management information system. Health Policy and Planning, 19(4), 187-198. https://doi.org/10.1093/heapol/czh024

Ndem, M. A., Angioha, P. U. \& Dike, E. (2020). Improving the Socio-Economic Wellbeing of Rural People: Analysis of the Impact of the Community and Social Development Project (CSDP) tn Odukpani Local Government Area of Cross River State, Nigeria. Asian Journal of Applied Sciences.8 (2), 88-94.

Nigeria Centre for Disease Control (2021). One Year of COVID-19 Response in Nigeriahttps://ncdc.gov.ng/news/324/one-year-of-COVID-19-response-in-nigeria

Ojong-Ejoh, M. U., Angioha, P. U., Agba, R. U., Aniah, E. A., Salimon, M. G., \& Akintola, A. (2021). Operating SMEs in the Face of the COVID-19 Pandemic in Calabar. Quantitative Economics and Management Studies, 2(4), 272-280. https://doi.org/10.35877/454RI.qems305

Ojong-Ejoh, M. U., Iji, M. E., Angioha, P.U. (2019).Curing Socio-Economic ILLS in Obudu Local Government Area: An Assessment of Non-Governmental Agencies Activities". Journal of Social Service and Welfare;1(2): 38-45.

Omang, T. A., \& Angioha, P. U. (2021). Assessing the Impact COVID-19Pandemic on the Educational Development of Secondary School Students.JINAV: Journal of Information and Visualization,2(1), 25-32. https://doi.org/10.35877/454RI.jinav261

Omang, T.A., Angioha, P.U.,Ojong-Ejoh, M.U. \& Abang, T. (2020). COVID-19Measures and the Exacerbation of Intimate Partner Violencein Calabar, Ijo-International Journal Of Social Science And Humanities Research., 3(12)83-94

Poudel, K., \& Subedi, P. (2020). Impact of COVID-19 pandemic on socioeconomic and mental health aspects in Nepal. International Journal of Social Psychiatry, 66(8), 748-755. https://doi.org/10.1177/0020764020942247 
Ronzi, S., Orton, L., Pope, D., Valtorta, N. K., \& Bruce, N. G. (2018). What is the impact on health and Wellbeing of interventions that foster respect and social inclusion in community-residing older adults? A systematic review of quantitative and qualitative studies. Systematic reviews, 7(1), 26. https://doi.org/10.1186/s13643$\underline{018-0680-2}$

Ukwayi, J.K., Angioha, P. U \& Ayi, A. B. (2018). Security Agencies and Kidnapping in Akpabuyo Local Government Area of Cross River State, Nigeria. International Journal of Humanities and Social Science Invention (IJHSSI), Volume 7 Issue 12 Ver. I, PP 49-58

United Nations Office for the Coordination of Humanitarian Affairs (2020). NGOs at the forefront of COVID-19 efforts with OCHA's pooled funds, https://www.unocha.org/story/ngos-forefront-COVID-19-effortsocha\%E2\%80\%99s-pooled-funds

World Bank. (, 2021). COVID-19 to Add as Many as 150 Million Extreme Poor by 2021. https://www.worldbank.org/en/news/press-release/2020/10/07/COVID-19-to-add-as-many-as-150-millionextreme-poor-by2021\#: : text $=$ The $\% 20$ COVID\%2D19\%20pandemic\%20is, severity\%20of\%20the\%20economic\%20contracti on.

World Food Programme (WFP)(2020). COVID-19 pandemic. https://www.wfp.org/emergencies/COVID-19pandemic

World Health Organisation (2021). WHO Coronavirus Disease (COVID-19) Dashboard. Situation by Country, Territory \& Area. https://covid19.who.int/table

World Health Organization. (2020a). Coronavirus disease (COVID-19) advice for the public. https://www.who.int/ emergencies/diseases/novel-coronavirus-2019/advice-for public 